\title{
Guru Profesional dan Tantangan Dunia Pendidikan
}

\author{
M. Syahran Jailani \\ Jurusan Pendidikan Agama Islam, Fakultas Tarbiyah dan Keguruan \\ IAIN Sulthan Thaha Saifuddin Jambi, Indonesia \\ Email:m.syahran@ymail.com . \\ Hp. 08127309578
}

\begin{abstract}
This article deals with professional teachers and challenges they face in the future. The performance of professional teachers demands hardwork to reconstruct their task and responsibility as educators. Nowadays, they bear burn critiques as researches posted them - Indonesian teachers are now in the critical situation. In the implementation of certification project, for example, the certified teachers performances were unlikely to match with students' success achievement. Research also confined that there were only 21.07 percents of State Elementary school teachers, twenty-eight point ninety-four percents of Private Elementary school teachers, fiftyfour point twelve percents of State Junior High school teachers, and sixty point ninety-nine percents of Private Junior High school teachers who deserved to teach. While there were only sixty-five point twenty-nine percents of State Senior High school teachers and sixty-four point seventy-three Private Senior High scholl teachers who deserved to teach.
\end{abstract}

Key Words: Professional Teachers, Education, Challenges of Education World

\begin{abstract}
Abstrak: Tulisan ini mengangkat isu seputar guru profesional dalam berbagai tantangan yang dihadapi. Kerja guru profesional menuntut kesungguhan para pendidik untuk merekonstruksi kembali akan tugas dan tanggung jawabnya sebagai pencerdas anak-anak bangsa. Sorotan dan kritikan yang sangat tajam ditujukan kepada guruguru kita. Berbagai riset, menempatkan guru-guru dan pendidikan di Indonesia berada suasana memprihatinkan. Misal saja, penyelenggaraan sertifikasi, meskipun guru-guru kita sudah memperoleh sertifikasi dengan tambahan gaji melalui tunjangan sertifikasi guru ternyata tidak berbanding lurus dengan prestasi hasil belajar siswa. Contoh lain, hanya 21,07 \% guru SDN layak mengajar. 28,94\% guru SD swasta layak mengajar. $54,12 \%$ guru SMPN layak mengajar, 60,99\% guru SMP swasta yang layak mengajar, dan 65,29\% guru SMAN yang layak mengajar, 64,73 guru swasta mengajar.
\end{abstract}

Kata Kunci : Guru profesional, Pendidikan, Tantangan Dunia Pendidikan.

\section{PENDAHULUAN}

Menarik menyimak pendapat pemikiran Abbas (2014) dalam kolom Opini Harian Kompas (Rabu, 5 Maret 2014) yang bertajuk “Disorientasi Pengelolaan Guru”, Abbas (2014) mencoba mengkritisi kebijakan pemerintah dalam pengelolaan guru di Indonesia. Pertama: studi Bank Dunia (2013) menunjukkan, program sertifikasi guru yang diselenggarakan Kementerian Pendidikan dan Kebudayaan selama beberapa tahun terakhir ternyata tak memberi dampak perbaikan terhadap mutu pendidikan nasional. Padahal, peyelenggaraan telah menguras sekitar $2 / 3$ dari total anggaran pendidikan yang mencapai 20 persen APBN.
Pada 2010, sebagai contoh, biaya sertifikasi Rp. 110 trilliun.

Kesimpulan Bank Dunia itu diperoleh setelah meneliti sejak 2009 di 240 SDN dan 120 SMP di seluruh Indonesia, melibatkan 39.531 siswa. Hasil tes antara siswa yang diajar guru yang bersertifikasi dan yang tidak untuk mata pelajaran Matematika, Bahasa Indonesia, serta IPA dan Bahasa Inggris diperbandingkan. Hasilnya, tidak terdapat pengaruh program sertifikasi guru terhadap hasil belajar siswa, baik di SD maupun di SMP. Demikian pula tingkat pengetahuan dan penguasaan materi yang diajarkan antara guru yang bersertifikasi dan yang tak bersertifikasi, juga hasilnya sama. 
Kedua: studi UNESCO (UIS-2009) menunjukan, untuk jenjang SD, rasio guru siswa $1: 16,61$, yang berarti seorang guru hanya mengajar 16-17 siswa. Rasio ini jauh lebih rendah dibandingkan Jepang $(18,05)$, Inggris $(18,27)$, bahkan Singapura $(17,44)$. Secara internasional, rata-rata di seluruh dunia rasionya 1:27,7 atau seorang guru dengan 27-28 siswa.

Keadaan serupa terjadi di jenjang pendidikan menengah. Data statistik persekolahan 2009/2010 menunjukkan, 48,8 persen SMP dan 47,2 persen SMA/SMK di Tanah Air memiliki kurang dari 180 siswa per-sekolah. jika digunakan rasio rata-rata internasional, setiap sekolah tersebut hanya perlu 6-7 guru. Jika jumlah siswa SD-SLTA secara keseluruhan 55,21 juta (BPS, 2012), maka diperlukan hanya sekitar 1,97 juta guru. Jika jumlah guru secara keseluruhan saat ini berkisar 2,92 juta, maka terdapat kelebihan sekitar satu juta guru. Namun, akibat ketiadaan konsep mekanisme pengelolaan dan distribusi guru yang komprehensif, jumlah guru yang melimpah itu tidak berdampak pada peningkatan mutu pendidikan. Ketiga: data menunjukkan, saat ini terdapat 415 lembagapendidikan tenaga kependidikan (LPTK), terdiri 12 eks IKIP, 24 FKIP PTS, dan 379 FKIP PTS. Sesuai amanat UU Sisdiknas, LPTK adalah perguruan tinggi yang di beri tugas menyelenggarakan program pengadaan guru pada pendidikan anak usia dini jalur pendidikan formal, pendidikan dasar, dan/atau pendidikan menengah, serta menyelenggarakan dan mengembangkan ilmu kependidikan dan non-kependidikan. Namun, pasca konversi IKIP jadi universitas, perhatian mereka tak lagi terfokus kepersoalan penyiapan guru professional, tetapi lebih berorientasi ke nonpendidikan. Akibatnya, dominasi penghasil guru muncul dari LPTK swasta yang umumnya beum berorientasi ke mutu. (Kompas, Rabu, 5 Maret 2014)

Mencermati problem-problem pendidikan di Indonesia hari ini sebagaimana dikemukakan di atas, adalah sedikit dari berbagai problem seputar dunia pendidikan kita yang terjadi. Sepatutnya dan selayaknyalah kita menata (merekonstruksi) ulang atau melakukan kontemplasi, apa yang sesung-guhnya terjadi dengan pendidikan kita (termasuk problem guru). Banyak istilah yang diungkapkan oleh pakar pendidikan dan praktisi pendidikan untuk menggambarkan betapa memilukannya raut wajah pendidikan kita saat ini. Surachmad (2004), menyebut pendidikan kita hari ini "sudah mati", Bochari (1994) mengistilahkan kondisi pendidikan kita dalam keadaan "mati suri", Tilaar (2002) memberi istilah lain dengan bahasa bahwa pendidikan kita diantara "menara gading". Pendapat-pendapat para tokoh dan pakar pendidikan tersebut mengisyaratkan kepada kita betapa mengkhawatirkan atau menurut penulis betapa gawatnya (emergency) pendidikan kita.

Banyak fenomena dan hal-hal aneh tapi nyata terjadi dalam dunia pendidikan kita. dalam bahasa Prayitno (2007) banyak sekali dalam dunia pendidikan kita terjadi "kecelakaan pendidikan". Surachmad (2004) "kriminalisasi pendidikan". Misalnya dalam proses pembelajaran dikelas terjadi kekerasan fisik dan mental terhadap siswa, sering muncul kasus pelecehan seksual terhadap siswa (anak didik), tindakan kekerasan yang menyebabkan meninggal seperti yang terjadi kasus hardiana akibat penusukan oleh oknum seorang guru di salah satu SMA di Jakarta, pelaksanaan ujian nasional yang banyak menimbulkan polemik, munculnya tim sukses, sindikat pencontekan yang diatur secara sistematis, sistem sertifikasi yang banyak muncul kritik, penggunaan dan penyaluran dana pendidikan yang terus bermasalah, penyediaan buku belajar yang dikomersilkan, guru yang mengajar asal-asalan, kesejahteraan guru yang dipertanyakan, kurikulum yang senantiasa berubah, sampai ke persoalan otonomi pendidikan dan kebijakan yang tidak konsisten dari pusat sampai daerah provinsi serta kabupaten atau kota.

Keterpurukan pendidikan di Indonesia dapat dilihat dari hasil yang diumumkan oleh United Nations For Development Programe (UNDP) pada tanggal 15 September 2004 yang mengumumkan secara serentak di seluruh dunia studi tentang kualitas manusia. Di dalam laporan tahunan itu Indonesia hanya menduduki posisi 111 dari 177 negara. Posisi ini jauh dibawah negara tetangga, Malaysia dan 
Singapura. Posisi 10 dari 14 negara berkembang dikawasan Asia Pasifik. Penelitian terhadap kualitas pendidikan dasar oleh Global Campaigh For Education tahun 2005 Indonesia menempati rangking 10 dari 15 negara Asia Pasifik dibawah India, Kamboja, Bangladesh, Vietnam, China, Fhilipina, Srilangka, dan Malaysia. Dari aspek kualitas input, pendidikan,dari data yang diumumkan. Indonesia berada diperingkat 14 atau nilai (E) paling jelek dari negara-negara Asia Pasifik.

Sebagai hasil perbandingan sederhana, berdasarkan laporan Human Development Index (HDI) tahun 2002 saja, oleh UNDP, Indonesia mendapat nilai 0,684 atau rangking 110 dibawah Vietnam yang mendapat nilai 0,688 urutan 109, Cina 0,762 urutan 96, Fhilipina 0,754 urutan 77, Thailand 0,762 urutan 70, Malaysia 0,782 urutan 59, Brunai Darussalam 0,856 urutan 32 , Singapura 0,885 urutan 25 , dan jepang 0,933 urutan 9. Kemudian berdasar laporan Human Development Index (HDI) tahun 2005 oleh UNDP, Indonesia masih tetap berada diposisi 110 dari 177 negara. Indikator dari penilaian ini mengacu pada pengembangan atau pembangunan manusia berdasarkan, yaitu: (1) pendidikan/ pengetahuan (knowledge), (2) kesehatan (a long and healty life), dan (3) kelayakan standar hidup ( $a$ decent standar of living), (Lihat S. Samba, 2007: 7-10).

Memang sorotan paling tajam diarahkan pada kualitas guru. Diakui kebanyakan kualitas guru belum profesional dan belum memadai untuk menjalankan tugas sebagaimana disebut dalam pasal 39 UU No. 20 tahun 2003 tugas dan kewajiban guru yang berbunyi yaitu merencanakan pembelajaran, melaksanakan pembelajaran, menilai pembelajaran, melakukan pembimbingan, melakukan pelatihan, melakukan penelitian hasil, dan melakukan pengabdian masyarakat. Bahkan sebagian dari guru-guru di Indonesia dinyatakan "tidak layak mengajar". Demikian pendapat Tamba (2007: 10). Sebagai perbandingan, dapat dilihat dari data tahun 2002-2003 diberbagai satuan pendidikan untuk guru SD yang layak mengajar hanya $21,07 \%$ untuk negeri dan 28,94\% swasta, untuk guru SMP yang hanya layak mengajar $54,12 \%$ (negeri) dan 60,99\% (swasta), sedang guru
SMA yang layak mengajar 65,29\% (negeri) dan $64,73 \%$ (swasta) dan guru SMK yang layak mengajar 55,49\% (negeri) dan 58,26\% (swasta).

Kita akui secara jujur, pemerintah terus berupaya untuk menjawab kritikan dan masukan yang ditujukan untuk meningkatkan mutu pendidikan terutama berkaitam kualitas guru kita melalui berbagai upaya, misalnya kebijakan dengan menyempurnakan Undang-Undang Sistem Pendidikan No. 2 tahun 1989, UndangUndang Sistem Pendidikan No. 20 tahun 2003, Undang-Undang Guru dan Dosen No. 14 tahun 2005, dan Peraturan Pemerintah Nomor 19 tahun 2005 tentang Standar Nasional Pendidikan dan perkuat dengan Peraturan Pemerintah Nomor 32 tahun 2013, perubahan atas Peraturan Pemerintah Nomor 19 tahun 2005. Terakhir, pemberian tunjanagan sertifikasi guru.

Berbagai upaya telah dilakukan oleh pemerintah, lembaga-lembaga pendidikan, kritik para pakar pendidikan, lembaga swadaya masyarakat (LSM) pendidikan, praktisi pendidikan, pelaku pendidikan dan stakeholder lainnya, yang kesemuanya itu memiliki satu tujuan yaitu bagaimana mutu guru bisa meningkat dan dan kemampuan guru-guru kita mampu sejajar dengan bangsa lain yang sudah maju. Pertanyaannya kemudian yang muncul mengapa kualitas guru kita masih rendah alias tidak profesional ? untuk menjawab pertanyaan ini, menurut penulis diantara problem utama kualitas guru kita rendah adalah apa yag dikemukakan Prayitno (2008 : 1) mengatakan karena " tidak dipraktekannya ilmu pendidikan dan merajalelanya kecelakaan pendidikan merupakan dua hal yang menjadi akar rendahnya mutu pendidikan ".

\section{HAKIKAT DIMENSI GURU PROFESIONAL}

Aktor utama dari semua yang dikemukakan di atas sesungguhnya adalah guru. Karena skenario yang diharapkan berjalan tidaknya sebuah proses pendidikan/ pembelajaran sangat bertumpu pada sosok guru, sekalipun Ishikawa dalam teori Fishbone Analisys sebagaimana di kutip Maryunis (1998) menyebut komponen utama dalam pembelajaran tidak hanya guru saja tetapi ada komponen 
lainya, seperti, ada murid, ada bahan ajar (content), ada media dan strategi, fasilitas sarana pendukung, ada lingkungan pembelajaran yang kondusif serta evaluasi yang terprogram. Mengingat begitu beratnya beban dan tanggungjawab yang disandang/dipikul seorang guru, maka tuntutan dunia pendidikan untuk memiliki guru yang berkulitas/ kemampuan profesional sangat diharapkan. Dambaan dan keinginan guru yang profesional dan punya kompetensi tidak hanya datang dari kalagan siswa, orang tua, pengamat pendidikan, penentu kebijakan, dan stakeholder lainnya, tetapi keinginan kuat guru yang profesional dan punya kompetensi itu muncul dari lubuk hati yang paling dalam para guru itu sendiri. Membentuk, membina dan mewujudkan guru profesional tidaklah semudah ketika kita mengucapkannya, banyak tahapan-tahapan,fase-fase, proses yang harus dilalui, dan beberapa indikator serta syarat-syarat yang mesti ditempuh.

Usaha peningkatan kualitas guru yang profesional didasari satu kebenaran fundamental, yakni kunci keberhasilan mempersiapkan dan menciptakan guru-guru yang profesional, yang memiliki kemitmen dan tanggun jawab yang baru untuk merencanakan pendidikan masa depan. Pada dasarnya peningkatan kualitas diri sesorang guru harus menjadi tanggung jawab diri pribadi sang guru. Untuk itu diperlukan adanya kesadaran pada diri guru untuk senantiasa dan secara terus menerus menigkatkan pengetahuan dan kemampuan yang diperlukan guna peningkatan kualitas kerja sebagai pendidik profesional. Kesadaran ini akan timbul dan berkembang sejalan dengan kemungkinan pengembangan karir mereka. Oleh karena itu pengembangan kualitas guru harus dikaitkan dengan perkembangan karir guru sebagai pegawai, baik negeri maupun swasta. Gambaran yang ideal adalah bahwa kepangkatan, pendapatan dan karir, dalam hal ini jenjang jabatan dan kepangkatan merupakan hasil dari peningkatan kualitas seseorang selaku guru. Proses dari timbulnya kesadaran untuk meningkatkan kemampuan profesional dikalangan guru, timbulnya kesempatan dan usaha, meningkatnya kualitas profesional sampai tercapainya jenjang kepangkatan dan jabatan yang tingg, memerlukan iklim yang memungkinkan berlangsungnya iklim kondusif, objektif dan transfaran.

Menurut Zamroni (2003: 32) mengemukakan bahwa "iklim yang kondusif hanya akan muncul apabila dikalangan guru timbul/memiliki hubungan kesejawatan yang baik, harmonis, dan objektif. Mengajar, hanya dapat dilakukan dengan baik dan benar oleh seseorang yang telah melewati pendidikan tertentu yang memang dirancang untuk mempersiapkan guru. Dengan kata lain, mengajar merupakan suatu profesi. Sejalan dengan perkembangan ilmu pengetahuan dan dinamika perubahan masyarakat, Selanjutnya, Zamroni (2003: 34) menyebut ada dua kecendrungan muncul berkaitan dengan profesi guru,yaitu: pertama, proses mengajar menjadi sesuatu kegiatan yang semakin bervariasi, komplek, dan rumit. kedua, ada kecendrugan pemegang otoritas sruktural, ingin memaksakan kepada guru untuk memergunakan sesuatu cara mengajar yang kompleks dan sulit, sebagai akibatnya guru dituntut untuk menguasai berbagai metode pembelajaran dan diharuskan menggunakannya.

Zamroni (2003: 35) mengemukakan, bahwa pekerjaan profesional dapat dikelompokan ke dalam dua kategori, yaitu: hard profession dan soft profession. Suatu pekerjaan dapat dikategorikan sebagai hard profession apabila pekerjaan tersebut dapat didetailkan dalam perilaku dan lagkah-langkah yang jelas dan relatiif pasti. Pendidikan yang diperlukan bagi profesi ini adalah menghasilkan output pendidikan yang dapat distandarisasikan. Artinya, kualifikasi lulusan jelas dan seragam di manapun pendidikan itu berlangsung. Dengan kualifikasi ini seseorang sudah mampu dan akan terus mampu melaksanakan tugas profesinya secara mandiri meskipn tanpa pendidikan lagi. Pendidikan pilot dan kedokteran merupakan contoh yang tepat untuk mewakli kategori hard profesion. Sebaliknya, kategori soft profession adalah diperlukan kadar seni dalam melaksanakan pekerjaan tersebut. Impikasi dari kategori soft profession dari waktu kewaktu harus ditingkatkan melalui latihan, loka karya, workshop, in-service training dan pelatihan berjenjang, baik formal maupun nonformal, agar 
dapat melaksanakan tugas pekerjaannya sesuai kebutuhan dan perkembangan masyarakat, termasuk kedalam contoh kategori soft profession ini diantara ialah guru, dan advokat.

Menurut para ahli, kata "profesi" berasal dari kata "profession" bahasa Inggris," Professus" bahasa latin . Kata profesi dapat di artikan dengan pekerjaan, dengan mata pencaharian atau okupasi (occupation). Profesi juga bisa berarti suatu pekerjaan atau jabatan yang menutut pendidikan khusus yang tinggi dan rangkaian latihan yang intensif dan panjang ( Bochari.2001: 104). Sementara menurut Yamin (2006:30) definisi profesional, khusus diperuntukkan dalam bidang olahraga dan seni, di dalamnnya ada unsur "pemain bayaran" dan ada pula " pemain amatiran". Definisi menurut sosiologi, mendefinisikan profesi merupakan model bagi konsepsi pekerjaan yang diinginkan, dicit-citakan. Good's dictionary of education sebagaimana dikutip Yamin (2006:30) mendefinisikan sebagai "suatu pekerjaan yang meminta persiapan spesialisasi yang relative lama di perguruan tinggi dan harus dikuasai serta memiliki suatu kode etik yang khusus".

Volmer dan Mills (1996), Mc Cully (1969), Sagala (2000) sama-sama mengartikan profesi sebagai spesialisasi dari jabatan intelektual yang diperoleh melalui studi dan training, bertujuan menciptakan keterampilan, pekerjaan yang bernilai tinggi, sehingga keterampilan dan pekerjaan itu diminati, disenangi oleh orang lain, dan dia dapat melakukan pekerjaan itu dengan mendapat imbalan berupa bayaran, upa dan gaji (payment). Ahmad Tafsir (2004: 112) mengemukakan ada dua kriteria pokok profesi, yaitu: (1) merupakan panggilan hidup, (2) keahlian.Kriteria panggilan hidup sebenarnya mengacu kepada pengabdian/dedikasi. Kriteria keahlian mengacu pada mutu layanan. Jadi pekerjaan profesi sangat didukung oleh teori yang telah dipelajari, Seorang profesional dituntut banyak belajar, membaca dan mendalami berbagai teori yang dilakoni, Suatu profesi bukanlah sesuatu yang permanen, ia akan terus mengalami perubahan dan seiring kebutuhan umat manusia. Jadi pekerjaan dan aktivitas yang disandang oleh guru adalah suatu pekerjaan yang memerlukan pengetahuan, keterampilan, kemampuan, keahlian dan talenta yang diharapkan akan mampu memberikan sesuatu yang bermakna kepada siswa (anak didik) sebagaimana yang diharapkan.

Guru profesional menurut Gilbert $\mathrm{H}$ Hunt (dalam Rosyada, 2004:11-114), memiliki, yaitu : (1) sifat; guru yang baik harus memiliki sifat-sifat antusias, stimulatif, mendorong siwwa untuk maju, hangat, berorientasi pada tugas dan pekerja keras, toleran, sopan, dan bijaksana, bias dipercaya, fleksibel dan mudah menyesuaikan diri, demokratis, penuh arapan bagi siswa, tidak mencari reputasi pribadi, mampu mengatasi streotife siswa, bertanggung jawab terhadap kegiatan belajar siswa, mampu bertanggung jawaba terhadap kegiatan belajar siswa, mampu menyampaikan perasaannya, dan memiliki pendengaran yang baik, (2) pengetahuan; guru yang baik juga memiliki pengetahuan yang memadai dalam mata pelajarn yang diampunya, dan terus mengikuti kemajuan dalam bidang ilmunya, (3) apa yang disampaikan; guru yang baik juga mampu memberikan jaminan bahwa materi yang disampaikannya mencakup semua unit bahasan yang diharapkan siswa secara maksimal, (4) bagaimana mengajar, guru yang baik manpu menjelaskan berbagai informasi secara jelas, dan terang, memberikan layanan yang variatif, menciptakan dan memilihara momentum, menggunaan kelompok kecil secara efektif, mendorong semua siswa untuk berpartisifasi, memonitor dan bahkan sering mendatangi siswa, mampu mengambil berbagai keuntungan dari kejadia-kejadian yang tidak diharapkan, memonitor tempat duduk, senantiasa melakukan formatif tes dan post test, melibatkan siswa dalam toturial atau pengajaran sebaya, memggunakan kelompok besar untuk pengajaran instruksional, menghindari kesukaran yang kompleks dengan menyederhanakan sajian informasi, menggunakan beberapa bahan tradisional, menunjukkan pada siswa tentang pentingnya bahan-bahan yang mereka pelajari, menujukkan proses berfikir yang penting untuk belajar berpartisifasi dan mampu memberikan perbaikan terhadap kesalahan konsepsi yang 
dilakukan siswa, (5) harapan; guru yang baik mampu memberikan harapan pada siswa, mampu membuat siswa akuntabel, dan mendorong partisipasi orang tua dalam memajukan kemampuan akdemik siswa, (6) reaksi guru terhadap siswa; guru yang baik biasanya menerima berbagai masukan, resiko, dan tantangan, selalu memberikan dukungan pada siswanya, konsisten dalam kesepakatan dengan siswanya, bijaksana terhadap kritik siswa, menyesuaikan diri dengan kemajuankemajuan siswa, pembelajaran yang memperhatikan individu, mampu memberikan jaminan kesetaraan partipasi siswa, mampu menyediakan waktu yang pantas untuk siswa bertanya, cepat dalam memberikan feedbeck bagi siswa dalam membantu mereka belajar, peduli dan sensitive terhadap perbedaan latar belakang sosial ekonomi dan kultur siswa, mampu menyesuaikannya dalam menghadapi berbagai perbedaan, (7) manajemen; guru yang baik juga harus mampu menunjukkan keahlian dalam perencanaan, memiliki kemampuan dalam pengelolaan kelas sejak hari pertama dia bertugas, mampu mengatasi gangguan yag muncul ketika terjadi proses pembelajaran, dan tetap dapat menjaga siswa untuk tetap belajar dengan sukses.

Suparno (2004:47-50), guru profesional itu adalah memiliki kepribadian yang utuh, yaitu : (1) guru harus bermoral dan beriman; hal ini penting karena salah satu tugas guru adalah membantu anak didik bertaqwa dan beriman serta menjadi anak yang baik, (2) guru harus mempunya aktualisasi diri yang tinggi. Aktualisasi diri disini adalah sikap bertanggung jawab, (3) guru mampu berkomunikasi dengan baik. Komunikasi yang baik akan membantu proses pembelajaran dan pendidikan terutama pada level dasar dan menengah.Banyak kasus, guru yang memiliki pengetahuan yang luas, tetapi tidak mampu berkomunikasi dengan siswa (anak didik) dengan baik, (4) guru harus disiplin. Setiap aktivitas hendaknya menerapkan disiplin yang tinggi, karena kunci sukses salah satunya adalah disiplin, dan kita sangat mudah diucapkan, dilaksanakan sangat sulit, (5) guru dituntut untuk belajar terus agar pengetahuannya tetap segar. Guru tidak boleh berhenti belajar.
Beberapa kriteria dan syarat yang dikemukaka di atas belumlah sempurna/lengkap manakala kita tidak memunculkan aspek kepemimpinan dalam diri seorang guru. Nilainilai kepemimpinan telah ada dalam diri setiap orang termasuk guru. Kepemimpinan merupakan potensi yang dimiliki setiap manusia, dan sudah menjadi "sinqua non" pada sosok guru sesunggunhnya telah melekat/sudah ada aspek kepeminpinan dalam kesehariannya. Hanya saja, apakah bakat/talenta dan sifat-sifat kepemimpinannya sebagai sosok seseorang guru telah memberikan pengaruh yang positif bagi dirinya, bagi siswa dan lingkungan pembelajaran disekitarnya atau sebaliknya. Tanpa disadari sebenarnya guru telah secara bersamaan merefleksikan sifat dan bakat kepemimpinan dalam kegiatan pembelajaran. Untuk itu kepemimpinan pada diri guru harus kokoh dan kuat, mengingat apa yang di praktekkan dalam aktivitas kehidupan, interaksi pembelajaran di sekolah dan dimana pun guru berada, menjadi bagian dari kemimpinan yang ia bawa. Guru profesional juga harus didukung kepemimpinan yang berprinsif, berwibawa dan kharismatik. Untuk itu, Covey (1996: 29-37) menyebut beberapa ciri-ciri pemimpin yang efektif dengan berprinsif, yaitu: (1) mereka terus belajar. Artinya mereka terus menambah kemampuan untuk mendapatkan pelatihan/ pendidikan, kursus/penataran, workshop/ seminar, mendengarkan orang lain, (2) mereka berorientasi dapa pelayanan. Mereka punya prinsif bahwa hidup ini adalah sebuah misi bukan karir. Mereka selalu memikirkan orang lain, mereka selalu mengingat apa tugas dan tanggung jawab yang diembannya, mereka yakin tidak ada beban yang harus dipikul, mereka selalu siap dan bersiap melakayani orang lain, (3) prinsif membangkitkan energi yang positif. Mereka dapat mengubah keadaan yang negative menjadi positif, yang lemah menjadi lebih kuat, yang kacau menjadi stabil, mereka bersikap optimis, berfikir positif, (4) mereka memiliki antusiasme yang tinggi, punya harapan dan keyakinan, menciptkan perdamaian dan keharmonisan, bukan sebaliknya, merobah kekuatan destruktif menjadi konstruktif, (5) mereka membuat hidup seimbang. Mereka tidak mengambil sesuatu seluruhnya, tetapi bukan 
tidak ikut mengambil sama sekali, (6) mereka memandang hidup hidupa sebagai pengalaman. Mereka menikmati hidup karena perasaan aman datang dari dalam diri sendiri bukan dari luar, (7) mereka adalah pembaharu. Mereka hampir selalu mengubah situasi kedalam keadaan yang lebih baik, (8) mereka selalu memperbaiki diri. Secara terus membenahi keempat dimensi yang dimiliki manusia: fisik, mental, emosi dan spritulitas.

\section{ALTERNATIF SOLUSI MENGANGKAT HARKAT GURU PROFESIONAL}

Bochari (1994: 51) dalam bukunya
"Ilmu Pendidikan dan Praktek Pendidikan
dalam Renungan"; mengatakan bahwa, mutu
pendidikan itu pada akhirnya adalah
keseluruhan dari mutu setiap perjumpaan guru -
murid yang terjadi selama jangka waktu tertentu.
Suatu perjumpaan guru - murid dapat dikatakan
bermutu apabila perjumpaan itu tadi berdampak
atau terasa membantu perkem-bangan diri murid.
Sebaliknya suatu perjumpaan guru - murid
harus dipandang tidak bermutu apabila
perjumpaan tadi tidak berdampak mendorong
atau tidak terasa mendorong perkembangan diri
murid, atau lebih parah lagi menghambat
perkembangan diri murid.

Jadi perjumpaan guru dan murid yang ditandai oleh murid-murid yang mengantuk atau murid-murid yang tidak mengerti apa yang sedang dibicarakan guru bukanlah suatu perjumpaan yang bermutu. Guru yang tidak menguasai medium pendidikannya, yang tidak menguasai vak-nya, tidak mungkin mampu menyelenggarakan perjumpaan guru - murid yang bermutu. Jadi kalau selama satu tahun pelajaran perjumpaan guru - murid yang terjadi di suatu kelas di suatu sekolah lebih banyak diwarnai oleh suasana serta peristiwa-peristiwa yang tidak mendorong perkembangan diri para siswa, maka keseluruhan proses pendidikan tidak dapat dipandang bermutu.

Lebih lanjut Suparno (2004: 52) menjelaskan bahwa, kalau pandangan ini dapat diterima, maka upaya meningkatkan mutu pendidikan harus difokuskan kepada upaya pengidentifikasian langkah-langkah yang interaksinya akan melahirkan perjumpaan guru - murid yang bermutu. Apa saja yang harus dilakukan kita dewasa ini, untuk membantu guru-guru kita di sekolah agar mampu mengadakan perjumpaan yang baik dengan muridnya dari hari ke hari, dari bulan ke bulan, dari tahun ke tahun ?. Kalau semua upaya yang telah dicoba selama ini revisi kurikulum, perbaikan program pendidikan guru, pengadaan buku-buku, menaikkan kesejahteraan guru. Seluruhnya kita hubungkan dengan masalah menciptakan perjumpaan guru - murid yang baik ini, maka minimal akan terjawab pertanyaan tentang bagaimana meningkatkan mutu pendidikan. Karena revisi kurikulum dirancang bagaimana muatannya, dilakukan untuk menimbulkan perjumpaan guru - murid yang lebih baik. Program pendidikan guru harus dikembangkan untuk menimbulkan perjumpaan guru - murid yang bermutu ! buku pelajaran disusun untuk menimbulkan perjumpaan guru - murid yang baik!

Salah satu upaya yang sangat penting adalah mengangkat harkat pendidikan ialah dengan menjadikan pendidikan dengan bertumpu dengan ilmu pendidikan (lihat Prayitno, 2008: 3-4). "Ilmu pendidikan" adalah "Ilmu para pendidik" mesti (jika tidak wajib) dihidupkan kembali (kalau memang ia sudah mati), harus dibuat sadar (kalau memang koma), harus diberi semangat, dibuat tegar dan diberdayakan (kalau memang tidak berdaya), dihargai dan dihargakan (kalau memang masih merupakan barang murah) dan ditegakkan sosok dan arahnya (jika memang ia disorientasi), dipupuk dan disuburkan (kalau memang kerdil), di paskan ukurannya untuk masing-masing pengguna (kalau memang kedodoran). Apa artinya pendidikan tanpa ilmu pendidikan; apa artinya pendidikan yang didalamnya penuh dengan kecelakaan pendidikan. Kita memerlukan ilmu pendidikan (IP) yang jelas sosok dan arahnya, solid dan dapat diterapkan dalam praktek pendidikan disegenap jalur, jenis dan jenjang pendidikan. Kita menginginkan adanya ilmu pendidikan yang bisa menjadi roh dan arah dalam pelaksanaan pendidikan dengan ilmu pendidikan (PENDIP). 
Mengambil pendapat Prayitno, berbagai teori dari buku-buku teks asing yang telah banyak diadopsi. Betapa indahnya dikumandangkan dan dipampangkan dalam berbagai diskusi, seminar, lokakarya dan penataran tentang pendidikan, namun di lapangan praktik pendidikan yang berlangsung adalah sekedar "intruksi-intruksi dari pendidik (guru) kepada peserta didik (siswa)". Betapa merdunya kita mendengar istilah quantum learning, active learning, learning revolution. Kegiatan belajar melalui pendekatan konstruktivisme sebagai teori dan praktis pembelajaran yang dilontarkan dalam latihan-latihan bagi para (calon) pendidik. Namun yang terjadi dilapangan pada umumnya baru sekedar "Lima Ha' yaitu hiasan, hapalan, keharusan, hardikan dan kehampaan. Apa yang indah dalam buku-buku teks itu belum menjadi roh dan arah dalam praktek pendidikan yang seharusnya memperkem-bangkan dan membesarkan peserta didik (Prayitno, 2008: 4).

Tugas dan fungsi pendidikan adalah untuk menjawab nilai-nilai harkat dan martabat manusia tersebut melalui potensi fitrah (Hasan Langgulung, 1986: 48). Pendidikan berkewajiban mengarah, membimbing manusia kearah kesempurnaan harkat dan martabat kemanusiaan. Prayitno (2005: 13) mengatakan pendidikan merupakan hajat hidup semua orang. Tanpa pendidikan seorang individu tidak akan menjadi manusia sebagaimana diharapkan oleh masyarakat dimana individu itu hidup.

Selanjutnya, Tilaar (2002) menyatakan bahwa hakikat pendidikan adalah proses individuasi artinya bahwa tindakan mendidik adalah tindakan yang dialogis. Tindakan pendidikan membantu mencari identitasnya melalui partisipasinya dalam dunia kehidupan bersama-sama dengan lingkunganya yang lain. Pertemuan didalam situasi-situasi pendidikan sebagai bentuk dari dunia kehidupan adalah situasi-situasi dialogis atau situasi-situasi individuasi. Di dalam kondisi tersebut proses pendidikan adalah suatu proses pengembaraan antara individu yang belum bersejarah memasuki dunia kehidupan yang semakin lama semakin terstruktur dalam bentuk kebudayaan. Di dalam proses tersebut peranan pemimpin apakah sebagai ibu, orang tua, pendidik (guru) berfungsi sebagai fasilitator peserta komunikasi. Di dalam proses tersebut, peranan pemimpin yang telah lebih berpengalaman akan membantu peserta didik untuk menemukan identitasnya dan pengembangan partisipasinya dalam dunia kehidupan.

\section{SIMPULAN}

Kajian dan pemikiran analitis sebagaimana tertuang di atas dapat tarik kesimpulan, sebagai berikut: pertama, Guru profesional pada hakikatnya adalah sosok guru yang memiliki kesadaran yang kolektif dan utuh akan posisinya sebagai pendidik. Memaknai sebagai guru tidak sekedar memenuhi kewajiban dan tangguung jawab sebagai pendidik di depana kelas, tetapi panggilan hati nuraninya sebagai pendidik seharusnya menjadi cemeti seorang guru untuk berbuat lebih baik dari sekedar memenuhi kewajiban administrasi. Kedua, Kemuliaan dan ketinggian derajat seorang guru profesional, akan di ukur sejauhmana ia mampu memberikan niali-nilai kebaikan kepada peserta didiknya. Ukuran kebaikan peserta didik dalam proses pembelajaran, akan menjadi barometer keberhasilan guru-guru menanamkan benih-benih keikhlasan dalam setiap pikiran, ucapan, tindakan dan perbuatan yang dituangkan dalam setiap aktivitas pembelajaran sehari-hari di sekolah. Ketiga, Pemahaman yang konprehensif, mendalam dan membumi para guru tentang ilmu pendidikan sebagai ilmunya para pendidik, semestinyalah merupakan cerminan penguasaaan kaidah-kaidah, nilai-nilai etika guru-guru yang siap menghadapi berbabagai problem dunia pendidikan, meskipun godaan, rayuan dan segudang janji manis senantiasa menanti di hadapan guru-guru.

\section{DAFTAR RUJUKAN}

Abas, H. 2014. 5 Maret 2014. Disorientasi Pengelolaan Guru. Harian Kompas, hlm. 13

Bochari, M. 1994. Ilmu Pendidikan dan Praktek Pendidikan Dalam Renungan. Jakarta: IKIP Muhammadiyah Jakarta Press. 
Bochari, M. 2001. Pendidikan Antisipatoris. Yogyakarta: Kanisius.

Covey. R. S. 1999. Principle-Centered Leadership. New York: Crown Business

Langgulung, H. 1986. Manusia dan Pendidikan Suatu Analisa Psikologi dan Pendidikan. Jakarta: Pustaka AlHusna.

Maryunis, A. 1998. Materi Kuliah Statistik. Padang: UNP Press

Rosyada, D. 2004. Paradigma Pendidikan Demokratis Sebuah Model Pelibatan Masyarakat dalam Penyelenggaraan Pendidikan.Jakarta: Kencana

Prayitno. 2005. Peta Keilmuan Pendidikan. Padang. UNP Press.

Prayitno. 2005. Sosok Keilmuan Ilmu Pendidikan. Padang. UNP Press.

Prayitno. 2008. Dasar Teori dan Praksis Pendidikan. Padang. UNP Press.
Samba, S. 2007. Lebih Baik Tidak Sekolah. Yogyakarta. LKIS.

Suparno, P. 2004. Guru Demokratis di Era Reformasi Pendidikan. Jakarta: Grasindo.

Undang-undang Sistem Pendidikan Nasional. 2005. Yogyakarta: Pelajar.

Tilaar. H.A.R. 2002. Perubahan Sosial dan Pendidikan Pengantar Pedagogik Transformatif Untuk Indonesia. Jakarta : Grasindo.

Tilaar. H.A.R. 2007. Mengembangkan Ilmu Pendidikan Berdimensi Global Di Indonesia. Jakarta: UNJ Press

Tafsir, A. 2004. Ilmu Pendidikan dalam Perspektif Islam. Bandung: Rosda

Yamin, M. 2006. Sertifikasi Profesi Keguruan di Indonesia. Jakarta: GP

Zamroni. 2003. Paradigma Pendidikan Masa Depan.Jakarta; Proyek PPM SMU

Surachmad, W. 2002. Implikasi Manajemen Pendidikan Nasional Dalam Konteks Otonomi Daerah (Makalah). Konaspi Jilid II Jakarta.UNJ 